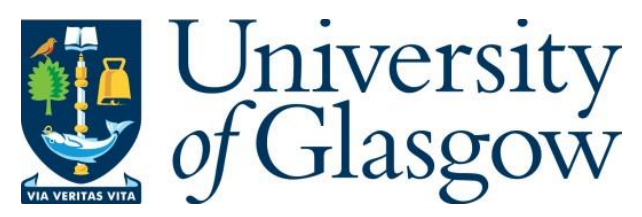

McLean, H. (2017) Hos in the garden: staging and resisting neoliberal creativity. Environment and Planning D: Society and Space, 35(1), pp. 38-56.

There may be differences between this version and the published version. You are advised to consult the publisher's version if you wish to cite from it.

http://eprints.gla.ac.uk/131726/

Deposited on: 17 April 2018

Enlighten - Research publications by members of the University of Glasgow http://eprints.gla.ac.uk 
This paper takes up the challenge of extending and enhancing the literature on arts interventions and creative city policies by considering the role of feminist and queer artistic praxis in contemporary urban politics. Here I reflect on the complicities and potentialities of two Torontobased arts interventions: Dig In and the Dirty Plotz cabaret. I analyse an example of community based arts strategy that strived to 'revitalize' one disinvested Toronto neighbourhood. I also reflect on my experience performing drag king urban planner, Toby Sharp. Reflecting on these examples, I show how market-oriented arts policies entangle women artists in the cultivation of spaces of depoliticized feminism, homonormativity and white privilege. However, I also demonstrate how women artists are playfully and performatively pushing back at hegemonic regimes with the radical aesthetic praxis of cabaret. I maintain that bringing critical feminist arts spaces and cabaret practice into discussions about neoliberal urban policies uncovers sites of feminist resistance and solidarity, interventions that challenge violent processes of colonization and privatization on multiple fronts.

Key words: feminist geography; queer geographies; arts interventions; creative city; cultural policy; neoliberal urbanism 
Over the past decade, public arts funding organisations and city boosters have deployed a range of 'creative city' (Peck, 2005) initiatives to catalyse investment in cities and neighbourhoods. Such strategies pressure community arts organisations and theatres to generate ticket sales and revitalize neighbourhoods. What kinds of feminist and queer women's artistic practice can these partnerships accommodate? What happens to such artistic practice when public funding apparatuses encourage theatres to program work that appeals to philanthropists and corporate partners? How are women artists carving out their own spaces of critical expression?

Feminist and queer scholars analyzing neoliberal 'creative city' policies provide several critical pathways to answer these questions. Some contend that community arts organisations are finding ways to craft innovative feminist community development collaborations with businesses and community groups from within this regime. However, feminist critics argue that, as public arts funders pressure arts organizations into achieving financial self-sufficiency, arts organizations tend to instrumentalize queer and women artists to the exclusion of politicized, critical feminist and queer work (Harvie, 2013; McRobbie, 2011). They argue that creative city partnerships mobilize artists and grassroots arts organisations to "clean up" neighbourhoods for investment (Deutsche, 1998; Levin and Solga, 2011). Moreover, as policy makers and city boosters value the arts for attracting capital and investment, feminist and queer critics charge that even counterhegemonic arts interventions become complicit in reproducing intersectional inequalities.

Meanwhile, feminist performance artist and theorist Moynan King contends that critical feminist and queer women artists are continually "resurfacing again and again” (King, 2011: 201) from the margins to resist their erasure with the radical aesthetic and political praxis of cabaret. However, from these liminal spaces, women artists can become entangled in exclusionary creative city initiatives by providing entrepreneurialized arts organisations with edgy feminist and queer artistic fare (Cowan, 2011). In this paper, I evoke Natalie Oswin's $(2005,84)$ claim that 
"ambivalent and porous" sites of queer complicity present new opportunities for re-working and resistance. In the examples I discuss, I demonstrate how women artists are contesting inequalities and nurturing new solidarities within the contradictory space of feminist cabaret.

This paper draws from and builds upon feminist and queer analyses of neoliberal creativity by analyzing the complicities and potentialities of two Toronto-based arts interventions. In the first half of the paper, I describe the activities of the Dupont Improvement Group (Dig In), an arts organisation striving to transform the disinvested, former manufacturing neighbourhood of Bloordale into a cultural hub for young families, artists and professionals (Dig In, 2015). I argue that, even though Dig In's activities ostensibly promoted alternative community development and supported queer and feminist arts organisations, the group also naturalized the production of depoliticized spaces of middle class feminism, homonormativity and white privilege. In the second half of the paper, I reflect on my experience performing drag king 'tool' for urban change Toby Sharp in the Dirty Plotz Cabaret as a strategy to critique the race and gender politics of exclusionary arts-led revitalization (Operation Snatch, 2013). Conceived of by Alex Tigchelaar, a feminist artist, performance theorist and activist, Dirty Plotz explored the historic and ongoing exclusion of women in the arts. I contend that, within the neoliberal creative city, feminist arts interventions like Dirty Plotz can become complicit in reproducing inequalities. But they are also active in generating what Jose Muñoz (1999) referred to as counterpublic disidentificatory acts that co-opt and rework exclusionary discourses through which minoritarian subjects are called to identify. Through these subversive acts, feminist and queer women artists make connections between the exclusionary politics of community-engaged urban revitalisation strategies, precarious labour in the culture and university sectors and the erasure of women in artistic movements. In these spaces, they also forge solidarities with diverse networks of artists and activists. 
For this paper I draw from empirical materials that I gleaned while engaging in my research and drag king performance. I base this analysis on: (1) popular media reports between 2008 and 2010; (2) 12 formal and informal interviews conducted in 2010 with Toronto-based arts workers, curators, Bloor Night Light participants and activists; and (3) participant observation at the Bloor Night Light events. Also, (4), my Toby reflections are based on three separate performances with Dirty Plotz.

This approach forms an embodied example of arts practice as research, as my Toby performance was my attempt to engage in the feminist act of translating research into practice (Cahill, Farhana and Pain, 2007). I do not claim to be an objective observer of social phenomena so much as an embodied and embedded scholar, interested in uncovering the dynamics of complex social and spatial relationships in order to open up the possibilities for creating more equitable and just cities. I acknowledge that my research process and analysis are informed by my multiple subject positions in relation to arts-based activism in Toronto: white settler, consumer of the arts within a neoliberal context, precarious researcher and university instructor. None of these positions place me as an objective observer, but rather as a situated participant with ongoing connections to and care for urban politics and feminist arts practice.

\section{Engineering 'Tolerance' and 'Creativity'}

Of late, scholars have shed much new light on the contradictory politics of Canadian public arts funding. Some contend that organizations distributing public grants via arms-length, peer reviewed processes (including the Canada Council for the Arts and the Ontario Arts Council) have worked in limited ways to open up space for underrepresented women artists and artists of colour in Canada's cultural sector (Godard, 2001). However, others claim that public arts funding regimes are part of what Himani Bannerji describes as a "multicultural inclusion model", 
a mode of political, economic and moral regulation used to manage the conduct of 'othered' categories: "immigrant, visible minority, new Canadian and ethnic" (Bannerji 2001: 201).

Since the mid-1990's, regulatory restructuring has deepened exclusion within the Canadian arts funding landscape. In this period, alongside cuts in social spending, federal funding to the Canada Council for the Arts dropped from \$105.5 million in 1991-1992 to \$88.8 million in 1997-1998 (Godard, 2001). Within these shifts, the public funding supporting access and equity in the arts evaporated, abandoning a new generation of artists (Walcott, 2001). Simultaneously public arts funding bodies, led by advisory boards made up of an increasing number of persons representing the interests of banks and corporations, rolled-out mixed-funding models that have extended corporate priorities and market discipline to artists and arts organization coercing them into acting entrepreneurially and developing networks in culture-led revitalization partnerships (Robertson, 2001).

Since the early 2000s, the rise and spread of the creative city policy trend has further intensified market-oriented arts partnerships (Florida 2002a, 2002b). The key premise of this now globalised neoliberal urban development script is that cash-strapped local governments in cities that have lost industrial and manufacturing employment should prioritize luring and retaining the 'creative class' (Evans, 2009; Peck, 2005,2011; Parker, 2008), a category constituted by university educated professions in the IT, knowledge industry and financial service sector. In a race to attract this 'class', municipal officials and city boosters have strived to reinvent cities and neighbourhoods with arts-led revitalization connecting arts organisations, business improvement associations (BIAs) and philanthropic partners.

Some scholars claim that the creative city policy trend opens up novel possibilities for artistic expression and community economic development. They contend that creative city collaborations democratize artistic practice (Boren and Young, 2013; Edensor et. al, 2009). 
Others credit culture-led revitalization with mobilizing assemblages of arts organisations and community groups that can foster inclusive feminist community economies (Rankin and Delaney, 2011). Such initiatives can promote social inclusion by supporting groups that work with underrepresented immigrant communities, queer youth and disabled residents (Bromberg, 2011).

However, feminist and queer scholars examining neoliberal urban policies and practices through a critical intersectional lens contend that the creative city regime ultimately deepens multiple inequalities (Catungal and Leslie, 2008; Parker 2008; McLean, 2014). This lens renders visible the uneven politics of place-based urban creativity strategies that strive to make over neighbourhoods into sites of consumption and play for middle class professionals (Creative Class Struggle, 2010). Within a neoliberal context, city officials download community economic development responsibilities on to neighbourhood-based groups that often program easy-toconsume artistic work that aligns with placemarketing initiatives (Grundy and Boudreau, 2008). As a result, such strategies often exclude critical feminist artists grappling with social and economic justice (Levin and Solga, 2011; Harvie, 2013). Instead these initiatives reproduce moralising, missionary-like narratives of benevolent middle class artists and community organisers assisting 'at risk' communities - sex workers, drug users, homeless residents -- in need of healing (Hubbard, 2003; Kwon, 2004). Also, as Leslie Kern (2010) claims, arts-led regeneration projects often cultivate gendered narratives of threat that legitimate efforts to securitise residential, commercial and public spaces via redevelopment planning. Such narratives reinforce liberal, middle-class feminism that avoids deeper structural analysis of the race, class and gender dimensions of contemporary inequalities (Fraser, 2013).

Tiffany Muller Myrdahl (2011) contributes to critical understandings of the gendered politics of creative city policies by demonstrating how this urban planning framework promotes the regulation and consumption of market-friendly LGBT subjectivities. Her work shows how culture-led revitalization projects often favour queer identities and practices that align with 
boosterist narratives of inclusivity, diversity and unity but police and exclude radical queer subjectivities deemed too risky (Hubbard, 2004, 2011; Oswin, 2008, 2012). This line of critique echoes Lisa Duggan's (2003) exploration of the contemporary production of spaces of homonormativity, a queerness that purports to "push for progressive causes such as rights to gay marriage and other 'activism' but at the same time...rhetorically remaps and recodes freedom and liberation in terms of privacy, domesticity, and consumption”. Duggan and others critique strategies that favour sanitized notions of diversity appealing to middle class gay and lesbian professionals (Hanhardt, 2013; Oswin, 2006) at the expense of marginalised residents, especially low income communities of colour, homeless residents, sex workers and disabled residents, all those deemed non-constitutive of desirable urban professionals (Hanhardt, 2013). Furthermore, feminist and queer critics argue that public-private partnership-led arts initiatives promoting queer diversity white wash the "bloody, violent consequences of neoliberal privatization" (Agathangelou et. al 2008:123) that dispossess and displace low-income communities, Indigenous communities and communities of colour.

An intersectional lens also draws attention to the subtle and not-so-subtle ways neoliberal creativity entrenches racialized inequalities. Mobilising colonial and imperialistic languages of light, diversity and inclusion (Ahmed, 2013), contemporary arts-led revitalization initiatives striving to reinvent neighbourhoods naturalise what Katherine McKittrick and Clyde Woods refer to as colonial "geographic desires bound up in conquest" (2007:7). For example, Toronto's Nuit Blanche international festival of contemporary art and the Luminato festival of creativity both promote urban revitalisation and diversity by inviting residents and festival-goers to 'shed light' on the city's 'dark' disinvested spaces with participatory arts interventions. These spatial metaphors valourise festival-goers and artists, as well as the corporate sponsors, banks and state funders supporting these events for bringing the light of creativity and urban development to neighbourhoods (Mclean, 2014). Such acts gloss over the violent erasure of precariously 
employed and working class communities of colour who have been pushed out of these downtown neighbourhoods. Furthermore, as Mi Won Kwon (2002) contends, arts interventions promoting community engagement and revitalization can naturalise colonial practices of separating and sorting 'healthy' and 'civically engaged' subjects from 'unhealthy' bodies and identities (Kern, 2015).

\section{Digging into Participatory Creativity}

While I was working alongside Toronto arts organisations for my $\mathrm{PhD}$ research, I developed a deeper understanding of how feminist and queer arts organisations can become entangled in the production of exclusionary space. For example, I learned about the Dupont Improvement Group (Dig In, 2015), an organisation implementing diverse arts projects to kick-start urban revitalisation in Bloordale. Dig In is an assemblage of businesses, homeowners' associations and ratepayers groups and artists committed to revitalizing the former manufacturing neighbourhood's storefronts, streets and alleyways into "clean, green and civil" spaces (Dig In, 2015). Over the past decade, the group has fostered reinvestment in the neighbourhood, an area the City of Toronto designated as "at-risk" due to the high percentage of families living below the poverty line, renters and new immigrants requiring community services (Birnbaum et. al, 2008). The group has collaborated with a wide range of feminist and queer arts organisations to implement participatory cultural interventions meant to raise awareness about social inclusion, crime and safety along Bloordale's commercial strip.

For example, every summer Dig In programs a neighbourhood-wide block party with Big on Bloor (BIG) (Big on Bloor, 2015), a network of West End Toronto BIAs, community and arts organizations to create "opportunities and events that improve the atmosphere and celebrate the area." Over the years, this event has featured an eclectic mix of feminist and queer positive arts organisations including artist run centres and range of Do-it-yourself arts collectives. Dig In has 
also initiated several participatory arts interventions in Bloordale to promote what the group's founder Dyan Marie described as "social change within a troubled community” (Balzer, 2007). In one ongoing project, the Green Spots, Dig In artists draw sprite-like creatures with vines sprouting out of them on cracked planters and in empty storefronts to signal Bloordale's potential for creativity, regeneration and growth (Eye Magazine, 2007).

In 2007, Dig In collaborated with the city-wide Nuit Blanche international festival of contemporary art to curate Bloor Night Light, a neighbourhood-wide arts-led revitalisation project. Nuit Blanche is a citywide all-night art festival supported by the City of Toronto, Scotiabank and other sponsors and is one of many initiatives promoted in the municipal government's 2003 Culture Plan for the Creative City (McLean, 2014). Since 2005, every September Nuit Blanche has transformed downtown Toronto into an interactive space of free, contemporary arts offerings.

Reiterating the feminist call to reclaim urban space, the overall aim of the event was to invite festivalgoers to participate in "taking back the night" (Balzer, 2007) in Bloordale according to Bloor Night Light organisers. Marie also stated that the event was an opportunity to engage artists and residents in ushering in "revitalization" and assisting Bloordale to "compete" (Balzer, 2007) with other Toronto neighbourhoods for recognition and investment. Centred on the theme of illumination, the Bloor Night Light project encouraged Bloordale shop-owners, residents, independent artists and festivalgoers to "shine a light" on the neighbourhood"s "potential" (Balzer, 2007) by adorning lamp posts and storefronts with papier-mâché lanterns (Balzer, 2007).

Dig In programmed Bloor Night Light activities in and around the House of Lancaster, a strip club owned and operated by the Chair of the local BIA. For one night, the Bloor Night Light artists transformed the space by featuring video performances on the club's television monitors and performance artists, dancers and musicians on the stripper's stage. According to Marie, re- 
inventing the House of Lancaster was an exciting opportunity to re-envision what she described as a "healthier" and more "productive" use for the space (Balzer, 2007).

In the week leading up to Bloor Night Light, local newspapers and artists' blogs celebrated Dig In for transforming Bloordale with this vibrant mix of interactive contemporary art and public space activism. One journalist applauded the group for "bravely" cleaning up a "degenerate" area known for "police sirens, drug deals and crack whores and the occasional spray of bullets" (Balzer, 2007). Meanwhile, a representative of Crime Stoppers, the non-profit organisation that brings together police services, community groups and residents in "the fight against crime”, praised Dig In for implementing “ a wonderfully original approach to improving communities" (Balzer, 2007).

Such a positive reception for Bloor Night light was not universal. Critics charged the group with further entrenching hierarchies and exclusionary dynamics in Bloordale (Interview with Bloordale performance artist, June 2009). One activist critiqued the group for transforming the neighbourhood into an all-night party zone for "middle class residents and hip stroller moms" (interview with Bloodale activist, June 2009). What particularly angered her was the fact the strippers, waitresses and bartenders who worked at the House of Lancaster were nowhere to be seen that night as they had been replaced by lantern-making and poetry readings. She also claimed that the Chair of the BIA was only involved in this event because he planned to eventually re-develop his section of Bloordale into condominiums.

Bloordale-based antipoverty activists and artists have also critiqued Dig In's broader community development activities. A few have raised concerns that, in local community meetings, some of the group's members referred to the sex workers working and living in the area as "crack whores" (Hutcheson, 2006). They pointed out that some of the more revanchist Dig In members had pressured municipal planners and City councillors to place curfews on the women's 
homeless shelter and to increase the policing of sex workers and massage parlours (interview with Bloordale activist, June 2009). Referring to the Green Spot creatures the group spray-paints on alley-way walls, one activist questioned the racism and settler colonial mentality that led to a community arts organisations claiming a neighbourhood that only exists because of the dispossession of the Six Nations of the Grand River, the Mississaugas of the New Credit First Nation, and the Five Nations of Iroquois (interview with Toronto artist, August 2009; also see Nagam, 2009)

\section{Feminist and Queer Creativity?}

Such an intersectional feminist and queer analysis of Dig In's activities uniquely uncovers the contradictory politics of community-engaged arts partnerships within the contemporary 'creative city.' On one hand, the projects illustrate how the ratepayer's group mobilised diverse queer and feminist artists, fostered community economies and promoted inclusive cultural activities. On the other, these examples illustrate how participatory arts become entangled in the production of spaces of moralising and depoliticised middle class feminism, homonormativity and white privilege.

Dig In's activities exemplify the progressive potential of diverse, feminist and queer partnerships co-evolving within the neoliberal creativity regime (Larner, 2011). The ratepayer group's hybrid partnerships with Big On Bloor and Bloor Night Light promoted cooperation, coproduction and alternative economies (Gibson-Graham, 2001). By collaborating with a wide range of feminist and queer artist-run centres, arts collectives and community centres in both events, Dig In supported underrepresented groups to share their work with a broader audience and develop networks. It can be argued that such strategies de-centre the entrepreneurial emphasis on competition that is endemic at a time of lean public funding, youth unemployment and neighbourhood disinvestment. 
However, Dig In's collaborations demonstrate how neoliberal creativity regimes ultimately reproduce liberal feminist values that further entrench hierarchies, not challenge them (Fraser, 2013). At first glance, Dig In's activities that were meant to "take back the night" and the strip club with interactive art gave the impression that their arts activities were sex-positive third wave feminist interventions. In reality, Dig-in's activities reinforced exclusionary attitudes by establishing a value system that elevated "creatives" over the bartenders, and suggested the waitresses and strippers were in need of "cleaning up" with lanterns. For the ratepayer's group these were productive programming choices because they attracted the "creative" citizenry that revitalization proponents value: artists, young families and urban professionals (Grundy and Boudreau, 2008). The project also established the ratepayer groups' power and privilege as “experts" saving the neighbourhood from disinvestment.

Dig In's Bloor Night Light events also reproduced what Kern and Mullings (2013) identify as gendered discourses of fear and safety that justify the rolling out of neighbourhoodscale redevelopment agendas. The ratepayer's and homeowners' groups and journalists reiterated discourses that constructed Bloordale's streets and shops as unsafe for women and families by describing the area as a "sketchy" space in articles (Balzer, 2007). This discursive framing simultaneously valourised Dig In's collective of "brave" artists and engaged community residents re-inventing the neighbourhood and stigmatised homeless shelter residents, sex workers and drug users. Derisive utterances such as "crack whore" conformed to ongoing strategies to remove women who do not align with what Hubbard and Wilkinson (2014:599) describe as the "normative ideals of cosmopolitan and civilized sexual comportment" that revitalization strategies promote. Moreover, such narratives cast Bloordale as an open frontier ripe for investment and development and echoed colonial imaginaries (Smith, 1979).

As Oswin contends, LGBTQ identities can become co-opted by neoliberal policies in "unintentional ways in which queerness is mobilized in complicity with exclusionary, rational, 
bureaucratic, and hierarchical logics" (Oswin 2014: 562). Viewed with such queer criticality, Dig-In's projects promoted a particularly homonormative production of space. In both the Big on Bloor and Bloor Night Light projects the group involved LBGT and feminist arts organisations in re-inventing the commercial strip with lively and diverse artistic fare. However, these collaborations ensnared these artists and organisations in marketing a queerness that aligned with strategies to securitize Bloordale. As the Crimestoppers representatives and city councillor's positive reviews of Bloor Night Light demonstrate, the arts programing complemented a preexisting combination of community economic development, revitalisation and neighbourhood safety strategies. Beyond the staging of a particularly depoliticized (Duggan, 2003) notion of queerness, the artists performing in Dig In events unintentionally supplemented ratepayer group's, city councillors and Crimestoppers in their regulation of queer bodies deemed threatening and abject: the trans sex workers and sex workers of colour living and working in the neighbourhood who were excluded.

Finally, the Bloor Night Light project mobilised what Ahmed (2012) identifies as the imperial language of cleaning up, brightening and enlightening. Such scripts and practices reinforce racialized and colonial tropes of dark and dirty spaces and subjects in need of cleanliness and guidance from "cleaner" European or white subjects. Also, the arts programming invited festivalgoers to participate in discovering and re-imagining the disinvested neighbourhood made possible by the dispossession Indigenous communities. Furthermore, these practices celebrated brave and creative new homeowners, artists and community-engaged citizens wiling to venture into and reinvent the "dark" streets, in reality home for precariously employed and lowincome Caribbean and East African residents (Rankin and Delaney, 2011). 


\section{Spaces of Criticality and Complicity in the Neoliberal City: Cabaret}

What might the possibilities be for the possibility of embodied aesthetic strategies for enacting alternative imaginaries, knowledges and creative resistance within constraining institutions that seem to have "absorbed any imagination and possibilities of change" (Peake and Riekers, 2013: 12)? Critical feminist and queer scholars and artists also contribute to our understanding of the potential and limitations of feminist performance interventions for contesting heteropatriarchal and white supremacist neoliberal regimes (Harvie, 2013; Bain and McLean, 2011). This line of enquiry shows how arts practitioners can become entangled in revitalization regimes that naturalise raced, gendered and classed hierarchies. Moreover, feminist and queer arts interventions also uncover strategies for what Aihwa Ong describes as building "solidarities across differences... for re-imagining new categories and political possibilities in the present" (Ong, 2013: 22).

In her reflections on New York's performance scene, Sarah Schulmann (2012) explains how, over the past few decades, public and philanthropic arts funding organisations that are striving to appeal to banks and corporations increasingly favour marketable and easy-to-consume work. Within this context, granting bodies tend to favour high-profile white, straight and gay male artists at the expense of queer women's contributions, especially intersectional work prompting difficult discussions about social justice, structural inequality, race and disability. King's (2011) reflections on her experience working with Buddies in Bad Times (a Torontobased theatre that produces and stages queer work) also describes how entrepreneurial funding regimes have undermined queer women artists in Canada. When Canadian public granting bodies pressured theatres to generate revenue via ticket sales in the mid 1990's, King notes how Buddies started to de-prioritize women's performance and emphasise well-recognized and funded male directors and performers. For King, women artists also inadvertently support the theatre with 
devalued and poorly compensated gendered care and social production work when they program their own independently produced projects.

Performing in cabaret is one way to investigate how creative feminist and queer artistic collaborations contest exclusionary artistic scenes. What cabaret performer and performance theorist TL Cowan describes as a "vital, if incoherent, form of entertainment and social commentary, a community-building, sustaining and transformative site of political activism and aesthetic innovation," (Cowan, 2012) cabaret remains a historic space of resistive artistic praxis. As Tigchelaar claims, angry, politicized women used to being pushed to the "fucking crazy making margins" (Operation Snatch, 2013) within arts movements find room to voice their frustrations in these spaces.

For queer artists of colour, cabaret can be a particularly radical space because it makes room for minoritarian subjects to engage in what José Esteban Muñoz (1999) refers to as disidentification. Artists of colour situate themselves both within and against the various dominant discourses of a disempowering white supremacist and heteronormative culture. Disidentification is the act of co-opting, recycling and rethinking this violently encoded meaning to include and validate minority identities. Through these acts, artists craft radical counterpublics, or "communities and relational chains of resistance that contest the dominant public sphere" and challenge the white heteronormativity of majoritarian cultural production (Muñoz, 1999:146).

According to Jack Halberstam (1997), cabaret's drag-king culture creates similar radical counterpublics for feminist and queer women performers to contest heteronoromative masculinities. Drag kinging is a particularly feminist and queer practice because it plays with the "regulatory fiction" (Butler 1990: 16) of masculine gender roles. By parodying and theatricalising repeated and scripted performances of dominant male masculinity, the drag king transgressively isolates the humour in gendered roles that sediments into what we commonly understand as the 
category 'man.' With these theatrical and inversionary acts, drag kinging also invites audiences to consider the hidden symbolic supports that give the impression that male social and political power is a result of their 'natural' abilities (Halberstam, 1997). Also, through humour, drag kings challenge audiences to consider the classist, racist, gendered and ableist performances that pass for our foundational normative modes of thought and behaviour in our everyday lives. These lines of enquiry evoke theorists who understand queer subjects as multiple and always differently positioned in relation to the dominant heteronormative order along lines of race, class, gender and more (Bell and Binnie, 2000; Oswin, 2004; Browne, 2006). Because queer subjects are unable to opt-out, they are continuously working with the conjunctures at hand and engaging in acts of revisioning (Oswin, 2004: Gibson-Graham, 2001).

The counterpublic space of cabaret is also subversive in its exuberant range of performances that tackle intersecting and divergent topics. This mix fosters what Cowan refers to as a "proliferating dialectic" (Cowan, 2012), a sense of relational knowing and being as the different acts intersect, diverge, speak to each other and engage the audience in conversation. A combination that can stir up "unpredictability, pleasure, risk excess, failure, challenge and confusion" (Cowan, 2012).

However, critics caution that cabaret is not always a site for radical expressions of subversive imagination that undermine and challenge the status quo. In her interrogation of Paris is Burning, a film about black gay men, drag queens and drag balls, bell hooks argues that these spaces and practices can reinforce the supremacy of white patriarchal capitalism (hooks, 1992). For her, contemporary consumer capitalism undermines the subversive power of drag balls, subordinating what were originally spaces to explore black gay life to spectacles for consumption. It's troubling for hooks that white researchers and consumers of culture tend to enact a white imperialist tradition of consuming representations of black culture as a source of entertainment 
and escape, and neglect to question how this white supremacist gaze reinforces racialised hierarchies of power.

Even as cabaret can become entangled in hegemonic power dynamics, it can also open up reflexive feminist and queer spaces that nurture oppositional politics and foster solidarities with other arts and activists scenes. Whereas collaborative arts initiatives are programmed to generate a unified sense of community (Joseph, 2002), feminist and queer cabaret thrives on the contradictory power of presenting line ups that can be complimentary, conflictual, transgressive or divergent (Cowan, 2011). According to Schulman (2011), such discomforting states are emotionally and politically expansive as they challenge us to consider our privilege and complicity in oppression; the uncomfortable may be what motivates us to imagine and enact strategies for reciprocity and resistance.

\section{Toby and Operation Snatch}

Here I augment my analyses of cabaret's potential for sparking critical dialogue and praxis by focussing on a particular case study. By reflecting on my personal experience performing Toby Sharp in the Dirty Plotz cabaret, I explore feminist and queer women artists' attempts to playfully resist historic and ongoing erasure of women in the arts.

Between 2006 and 2012 I crossed paths with Alex Tigchelaar of Operation Snatch in what Sarah Ahmed (2015) describes as the everyday "to-ing and fro-ing" of academic research. As we encountered each other at different arts and activist events, we discussed a wide range of topics regarding feminism, pop culture and urban politics. For me, these conversations were particularly compelling because Tigchelaar's artistic work and activist engagement reflect decades of accumulated embodied knowledge, including years of feminist and queer activist engagement in Toronto's performance scene. For years she co-directed and performed with the Scandelles, a flamboyant cabaret that gave voice to a dazzling array of powerful feminist, queer, 
trans and gender non-conforming comedians, dancers, body artists and musicians (Operation Snatch, 2015).

Over time, I hoped to incorporate some of her work with the Scandelles in my dissertation research. However, in a keynote speech she delivered for the York University's English Department's graduate student conference she scathingly critiqued those who she referred to as Simone de Beavers: women scholars who advance their research careers studying sex workers and sex worker artists and activists (see also Tigchelaar, 2012). Wary of my own beaver-like tendencies and inspired by feminist geographers who translate and circulate their work via artistic practice (Nagar, 2014; Pratt and Kirby, 2003), I took Tigchelaar's critique seriously. I asked her if I could contribute some of my research to a cabaret that she was in the midst of developing: Dirty Plotz, a homage to "poet, artist, proto-punk rocker, sexual libertine, fashion avatar and unrepentant trouble-maker" Elsa Von Freytag-Loringhoven, whose maiden name was Plotz (Tigchelaar, 2013). Sometimes referred to as the Baroness, Von FreytagLorninghoven's scatological aesthetic, artistic brilliance, and avant-garde spirit was instrumental to the New York Dada movement, though often confined to merely a footnote today (Gammel and Zelazo, 2011). Inspired by her life, work and this erasure, the cabaret explored the historic and ongoing exclusion of women in artistic movements by featuring surreal short films, comedy, hip-hop and body art.

Tigchelaar staged Dirty Plotz three times between 2013 and 2014. The cabaret was part of the Rhubarb Festival of contemporary performance at Buddies in Bad Times Theatre in February 2013 then included as part of Buddies' Pride week activities in June. A year later, Dirty Plotz performed for the Canadian Association for Theatre Research (CATR) and the Women's and Gender Studies et Recherches Féministes (WGSRF) at the 2014 Congress for Humanities and Social Sciences at Brock University. My contribution to the Dirty Plotz cabaret was in the guise of urban research guru Toby Sharp, a composite drag king character representing the masculine 
performances that circulate in contemporary urban practice and politics (McLean, 2013). To conjure Toby, I drew inspiration from my experiences working as an urban planner before I embarked on my doctoral research, the arts organizations I analyzed for my dissertation and the increasingly corporatized university edu-factory I encountered as a graduate student.

As a planner I worked for five years with community organisations negotiating largescale public-private neighbourhood 'revitalisation' projects in Toronto. Often I found myself a futile intermediary as these projects tore down disinvested public housing stock and replaced them with 'socially-mixed' condominium neighbourhoods and arts districts, an articulation of the rolling back of public support for infrastructure and the rolling out of market-oriented land-use planning (Kipfer and Petrunia, 2011). Working on such initiatives, I encountered a confident cadre of well-dressed white male urban planning consultants spearheading and overseeing 'creative' and 'green' 'revitalization' planning strategies. Consistently, these 'experts' seemed to lack any awareness of the structural causes of poverty, and the class, gender and race implications of 'revitalisation' projects removing precariously employed residents out of the city's downtown core to make space for condominium zones featuring pedestrian walkways, bike paths and new arts facilities (Rankin and Mclean, 2014).

Another inspiration for Toby can be traced back to my dissertation research when I encountered another network striving to 're-invent' Toronto's disinvested neighbourhoods: ratepayer and BIA-led urban revitalisation proponents such as Dig In, working to transform the streets, alleyways and parks near their homes into 'green' and 'creative' hubs. Mirroring the high power consultants I met as a planner, these community-engaged home-owner and business association groups confidently strived to re-invent neighbourhoods. As I have discussed previously in this article, they showed a dangerous lack of understanding that 'cleaning up' neighbourhoods of strip clubs, homeless shelters, sex workers and drug users to cultivate safe spaces posed serious risks to already marginalized residents. 
Creating Toby was also a way to work through my frustrations with the gendered performances of urban expertise that circulated in the neoliberal university. I had exited the realm of entrepreneurialised community development to examine planning through a critical feminist lens in academia. However, as I went about my work as a PhD student, a contract researcher and instructor, I found the politics of the university mirrored the politics of corporatized urban development. During this time, the University of Toronto's Martin Prosperity Institute had rewarded a few, highly paid celebrity urban experts to promote public-private 'creative city' partnerships (Creative Class Struggle, 2010). Meanwhile, university administrators cut back on women's and labour studies programs and relied upon a growing pool of casualised adjunct faculty and precariously employed administrative staff.

For Dirty Plotz, I channelled my growing sense of resentment with this hypocrisy into a series of Toby Sharp Ted Plotz talks, a satirical take on the Ted Talk format (inspirational public speaking events by philanthropists and designers originating in the Silicon Valley). The talks provided a platform to present a variety of fictitious Toby Sharp Hub for Innovation, Creativity and Competitiveness community-aged arts initiatives designed to re-invent Toronto neighbourhoods. Sporting a moustache and a mix of business casual and indie rock style to signal his hipness, Toby advised the audience about the importance of working together to "activate underutilized spaces, activate underutilized people and to reinvent our neighbourhoods for investment" (McLean, 2013). He also shared a collaboratively-produced short film about the fictitious Garden Hos project, a satirical take on 'green' and 'creative' strategies to re-invent neighbourhoods for investment. This project encouraged sex workers to leave their line of employment, and instead, forage for wild plants in the alleyways and sell them to young families and urban professionals in the Dufferin Grove farmers' market, a popular market space adjacent to Bloordale. In the film, Tigchelaar and her sex work activist friends dug up scraggly weeds with spades and shovels then pretended to sell them at a market stall. As a butch plant purchaser picks 
up one of the Garden Hos and runs off into the park's bushes, Toby's voiceover, satirizing contemporary community planning parlance, proclaimed, "this initiative promotes a healthy social mix".

With colourful power point presentations, each Toby Talk featured a series of faux public and private sponsored participatory arts initiatives meant to celebrate Toronto's 'ethnic' communities. While satirical, these interventions were based on actual food and festival arts initiatives that individual artists, festivals and community organisations have implemented in the city's disinvested neighbourhoods. In creating the power point, graphic designer Dana Sequin found an endless supply of community/creativity/innovation/hub fast policy (McCann and Ward, 2011) branding to poach from City of Toronto policy documents and festival websites.

In all three of the cabarets, Tigchelaar's dialectical curatorial approach contrasted the satirical, the serious and the surreal to activate a critical audience experience. For example, Nari (aka MC Jazz), an “unapologetically queer” (Nari, 2015) Egyptian poet and spoken word artist, immediately followed the clownish Toby's talks. With intense and rhythmic poems she called out the everyday racism and micro-aggressions she experienced living in a city that policy makers, politicians and journalists celebrate and market for its multicultural character, tolerance and ethnic harmony. This included a piercing and uncomfortable critique of white Canadians' tendency to use politeness as a way to avoid difficult discussions about race and histories of colonialism. She also expressed her rage at living on the receiving end of a masculinst and colonial exoticizing gaze as she went about her everyday life.

\section{Troubling Neoliberal Creativity in Contradictory Spaces}

In each of the cabarets, Tigchelaar and the Dirty Plotz artists reflected on the contradictory politics of staging politicized performance for theatres entangled in culture-led revitalization planning. As King points out, Buddies has played a pivotal role in supporting 
Toronto's queer women's arts scene. Meanwhile, she also points out how the theatre also has a history of under-supporting women artists while relying on their emotional labour, care work and diverse artistic offerings (King, 2011). Therefore, by performing at Buddies, the Plotz artists and I ended up assisting the theatre to cultivate an allusion of diversity and support for women artists that appealed to public funders and philanthropists and Pride programming (Walcott, 2001).

Likewise, despite the fact that Dirty Plotz was featured at Pride, many activists, including Tigchelaar and Plotz performer Jess Dobkin (Dobkin, 2015), critiqued the week of activities for morphing into a spectacularized corporate placemarketing machine designed to attract tourists and gay and lesbian professionals. To these arts-activists, Pride stands charged of accelerating the gentrification of downtown Toronto, processes that disproportionately displace low income queer youth and seniors, and queers of colour. Already vocal critics of these contradictions, Tigchelaar, Dobkin and the Dirty Plotz artists were unafraid to pillory the lack of support for women artists and the corporate culture of Pride week in their performances at Pride. For example, at the Pride cabaret, Toby invited the audience to join him and city councillors promoting Toronto-based arts-led regeneration projects in the Smirnoff Ice Vodka tent to discuss strategies for being 'tools' for community engagement and urban revitalization. This intervention shows how the "dynamic, responsive and consciousness raising" (Cowan, 2011) space of cabaret generates counterpublics of disidentificatory (Muñoz, 1994) collective work that critiques neoliberal urban policies and forges solidarities.

The Congress for Humanities and Social Sciences was also a contradictory site for politicized cabaret. The performance was an opportunity for the artists to transmit their critical work about historical and ongoing settler colonialism, racialized inequalities and the erasure of women from arts scene to a network of feminist scholars and arts practitioners. With these performative interventions, we engaged in decolonial and queer acts in an institutional space that disproportionately favours text-based approaches (Taylor, 2003). The cabaret was also an 
opportunity to share our embodied work that critiqued gentrification and explored women's unacknowledged care and social reproductive labour in the arts, community and education sector with a broad audience of women's and performance studies' students, professors and researchers.

By contrast, the precariously employed artists and adjuncts who make up the Plotz collective shared their experiences with tenured faculty in a well-resourced university bolstered by unjust labour practices. In our performances, we found ourselves offering up communityengaged fare for a corporatized university that also fostered neoliberal 'knowledge economy' partnerships in the Niagara Region (Majtenyi, 2015). Also, performing at Congress implicated us in the contradictory politics of the corporatized university sector that is interconnected with and continually reproducing neoliberal urban policies. With predictable similarity to Pride's cynical placemarketing, we provided the university event based in an institution also promoting real estate development via 'regeneration' partnerships with edgy cultural capital. Moreover, even as our performances satirized exclusionary community work and labour practices, we were fulfilling university 'knowledge mobilization' regimes that pressure scholars to extract the work of activists, residents and precarious community workers. These labour inequalities in the community sector are entwined with increasing inequalities in universities that increasingly rely on the precarious work of adjunct faculty and precarious staff, a labour force disproportionately made up of women and workers of colour (Great Lakes Feminist Geography Collective, forthcoming).

Instead of glossing over these tensions, the Dirty Plotz artists drew inspiration from what Puar and Rai (2002: 14) describe as "the networks of complicities that structure the possibilities of resistance" to contest this contradictory context in their performances. For example, TL Cowan's alter-ego Trixie Cane, a fake tanned, retired soccer mom and "mock, infomercial professional spokeslady" (Cowan, 2014) cheekily satirized the race and class privilege academic regimes reproduce. Specifically, she offered advice for "minority research targets," communities 
of colour that white academics exploit in their projects, to demand financial compensation from universities. In her performances, Cowan not only troubled the intersectional power dynamics reproduced in community-engaged research, but also pointed to strategies for forging solidarities with the communities that universities extract from. Meanwhile, Toby mocked the gendered politics of precarious university employment by lasciviously describing his excitement about working with 'flexible' women adjunct faculty on research projects. He also invited the audience to join him and the Brock University development office in forging community-university partnerships with property developers, knowledge industry partners and artists to re-invent the Niagara region into an up and coming arts hub. In these acts, I related the desperation of precarious labour in the education sector with the rise of community-university partnerships that can reinforce hierarchies and exclusion.

In all three of the Plotz performances, we also called attention to and troubled the scripting and staging of exclusionary arts-led revitalization initiatives and urban redevelopment. In the cabarets I engaged in the theatrical and satirical practice of drag kinging (Halberstam, 1997) to draw attention to, re-work and critique arts interventions designed to transform neighbourhoods into sanitised spaces of investment for artists, professionals and young families. By satirizing such interventions, the Garden Hos performance exposed how creative community greening projects produce spaces of hetero and homonormativity that naturalise and moralise dangerous narratives about sex workers. Also, the artists and activists who performed in the Garden Hos video queered community greening projects by practicing their own kind of 'social mix,' picking up the hos who sold the grubby plants in the trendy farmer's market. Moreover, by recycling word clouds and sound bites circulating in community development policies, we drew attention to and inverted the stylized repetition (Butler, 1990) of contemporary policies promoting "safe," "interactive" and "creative" communities that select only the queer subjects that align with entrepreneurial urban policies (Hanhardt, 2013). 
The "proliferating dialectic" (Cowan, 2011) of cabaret also created a space to contest racialised inequalities contemporary planning and university partnerships reproduce. In the Toby Plotz talks, Toby's tokenistic appropriation of 'diverse' communities mockingly reproduced Canada's liberal multicultural discourse (Bannerji, 2000) employed by culture-led community improvement projects. In his hyperbolic impersonations of contemporary culture-led revitalization discourse it becomes apparent that these initiatives flatten complex identities and communities into easy-to-consume 'diversity' suitable for white middle class sensibilities (Walcott, 2001). Tigchelaar's curatorial decision to program Nari's eloquent and angry spoken word performance directly after Toby's presentation further amplified the implicit white supremacy naturalised by this discourse. In stark contrast to Toby's naïve racist call to activate residents living in "underutilised priority neighbourhoods", Nari's poems illuminated the real everyday micro-violence and dispossession of racialised communities in Toronto. The discord produced by the two acts programmed side by side ruptured the false sense of unified community that culture-led regeneration projects promote while masking over the inequalities they deepen (Hanhardt, 2013).

Lastly, while the audiences of roughly one hundred and fifty people who attended the three cabarets they had limited capacity to challenge these entrepreneurialised spaces, it could be argued that the performers involved in Dirty Plotz are generating politicized interventions on multiple fronts and producing new sites of agency, possibility and resistance in Toronto's feminist performance scene. For example, in 2014, some of the Dirty Plotz artists partnered with a group of non-Indigenous and Indigenous artists to program the Basement Revue, a multidiscipline cabaret. This evening of performance and music raised funds for Indigenous-led campaigns promoting awareness about missing and murdered Indigenous women and encouraged solidarity and allyship and featured a roster of high profile artists. National radio shows and mainstream newspapers featured articles about the ongoing violence of settler colonialism in the 
week leading up to the event, bringing to public attention this violence against marginalised communities. The example of the Basement Revue cabaret typifies how the cabaret artists' work can forge complex network of solidarities to resist colonisation, privatisation and gendered violence. As opposed to arts projects instrumentalizing 'diverse' artists to 're-invent' neighbourhoods for 'creatives,' such acts foster dynamic minoritarian counterpublic scenes that can achieve wider public recognition.

\section{Conclusion}

Over the past decade, Canadian arts funders and city boosters have invested in public-private 'creative city' partnerships to 're-invent' neighbourhoods with culture. In a feverish race to keep up with this planning trend, cash-strapped city governments prioritize luring and retaining amenity-oriented and university-educated 'creatives'. They also download community economic development and placemarketing responsibilities on to ratepayers' and homeowners' associations. Within this context, community-based organisations promoting neighbourhood revitalization often mobilise grassroots and DIY artists and arts groups in strategies that aim to 'clean up' and securitize neighbourhoods to attract investment. Also, arts organizations tend to instrumentalize queer and feminist artists and arts organisations to the exclusion of politicized, critical feminist and queer work.

The examples of Dig In and Dirty Plotz point to how contradictory sites of feminist and queer complicity open up new opportunities for re-working and resistance in an era of neoliberal creativity. Despite their desire to kindle community economic development and engage feminist and queer arts groups, Dig In's participatory arts practices entrenched inequalities in the rapidly gentrifying Bloordale neighbourhood. Significantly, the art-based strategies meant to 'illuminate' and 'clean up' the neighbourhood that is home to a high number of low-income residents and new immigrants ensnared LGBTQ and feminist arts organisations and artists in exclusionary and 
competitive practices. As they strived to attract a 'creative' citizenry of young families, artists and middle class professionals, the Dig In projects naturalised the production of depoliticised feminist, homonormative and white privileged space. Reiterating colonial imaginaries and practices, the interventions also cast the neighbourhood as an open frontier ripe for investment and development.

My experience performing Toby with the Dirty Plotz also reveals the limits and potential of radical feminist and queer women's cabaret for co-opting and re-working the staging of neoliberal creativity. Dirty Plotz's collective of critical and angry feminist artists ask difficult questions about intersectional inequalities in their practice. However, in some ways, we were complicit in boosterist efforts to market and consume queer diversity. Even though we tackled the historic and ongoing erasure of women in artistic scenes, we also provided edgy theatrical fare for a massive, corporate-funded placemarketing strategy that has accelerated the displacement of low income queer youth and seniors and queers of colour from Toronto's downtown core. Also, by performing at Congress we provided critical feminist fare for university organisations that implement exclusionary real estate development deals, promote often-problematic communityengaged research, and rely on precarious labour.

The specific acts of subversion we staged with Dirty Plotz point to the generative potential for feminist artists to directly trouble the iteration of dominant creative city discourse and practice and connect current labour inequalities to power imbalances in the entrepreneurialized community, culture and university sectors. Many feminist artists are used to being pushed to the "fucking crazy making" margins and responding to the conjunctures they find themselves in. Through performative acts of disidentification, they continue to de-centre masculinist and competitive creative city policies and practices on multiple fronts. 


\section{References}

Agathangelou A, Bassichis D and Spira T, 2008, "Intimate investments:

Homonormativity, global lockdown, and the seductions of empire" Radical History

Review 100 120-143

Ahmed S, 2012, On Being Included: Racism and Diversity in Institutional Life (Duke University Press, Durham)

Ahmed S, 2014, "Sweaty concepts," Feminist Killjoys, http://feministkilljoys.com/2014/02/22/sweaty-concepts/

Archer B, 2007, “Painting the Town: At Bloor and Lansdowne, artist Dyan Marie sees the whole neighbourhood as a work of art" The Globe and Mail

Bannerji H, 2001, Inventing Subjects: Studies in Hegemony, Patriarchy and Colonialism (Anthem, London)

Balzer D, 2007, "Dyan Marie brightens up Bloor and Lansdowne's shadowing streets during the all night annual art party." Eye Magazine 27 September

Bell D and Binnie J, 2004, “Authenticating queer space: citizenship, urbanism and governance,” Urban Studies 41 1807-1820

Big on Bloor, 2013, Big on Bloor festival. http://bigonbloor.com/festival/

Birnbaum E, Cohen D, Mazer K and Wu J (2008) Bloor Improvement Group, Neighbourhood Review and Planning: Part 1, Economic Revitalization. Toronto. http://bigonbloor.com

Boren T and Young C (2013) "Getting creative with the 'creative city'? Towards new perspectives on creativity in urban policy. International Journal of Urban and Regional Research 37 1799-1815

Butler J, 1990, Gender Trouble: Feminism and the Subversion of Identity (Routledge, New York)

Bromberg A (2010) "Creativity unbound: Cultivating the generative power of noneconomic neighbourhood spaces.” In T. Edensor, D. Leslie, S. Millington and N. Rantisi (eds.) Spaces of Vernacular Creativity: Re-thinking the Cultural Economy, 214-225 (Routledge: London)

Browne K (2006) “Gender politics: citizenship, activism and sexual diversity," Gender, Place and Culture 13 321-322 
Cahill C, Farhana S and Pain R, 2007, "Participatory ethics: Politics, practices, institutions" ACME: International E Journal of Critical Geographies 6 304-318

Catungal J.P and Leslie L, 2009, "Contesting the creative city: race, nation, multiculturalism” Geoforum 40 701-704.

Catungal J.P. and Leslie D, 2009, "Placing power in the creative city: governmentalities and subjectivities in Liberty Village Toronto" Environment and Planning A 41 25762594.

City of Toronto, 2003, Culture Plan For a Creative City (City of Toronto press, Toronto)

Cowan T.L (2012) "Cabaret at Grunt: Up your community"

http://performance.gruntarchives.org/essay-cabaret-at-grunt.html

Creative Class Struggle (2010) https://creativeclassstruggle.wordpress.com/

DiCenzo M, 1998, Creative economies: new Right hegemony and cultural funding.

British Journal of Canadian Studies 13 253-264

Dig In, 2015, http://www.digin.ca/

Deutsche R, Evictions: Art and Spatial Politics (MIT Press, Boston)

Dobkin J, 2015, jessdobkin.com/

Duggan L, 2003, The Twilight of Equality? Neoliberalism, Cultural Politics and the Attack on Democracy (Beacon Press, Boston, MA)

Edensor T, Leslie D, Millington S and Rantisi N (eds), 2009, Spaces of Vernacular Creativity: Rethinking the Cultural Economy (Routledge, London)

Florida R, 2002, The Rise of the Creative Class And How It Is Transforming Leisure, Community and Everyday Life (Basic Books, New York)

Florida R, 2002b "Bohemia and economic geography" Journal of Economic Geography 2 $55-71$.

Fraser N (2013) Fortunes of Feminism: From State-Managed Capitalism to Neoliberal Crisis (Verso Books, New York)

Girls Rock Camp Toronto (2015) http://www.girlsrocktoronto.org/ 
Gammel I and Zelazo S, 2011, Body Sweats: The Uncensored Writings of Elsa von Freytag-Loringhoven (MIT Press, Boston)

Gibson-Graham J K, 2006, A Postcapitalist Politics (University of Minnesota Press, Minneapolis)

Godard B, 2001, "Re-signifying culture: notes from the Ontario culture wars," in Money, Value, Art: State Funding, Free-Markets, Big Pictures Eds A. Patterson and S. McKay (YYZ Books: Toronto)

Great Lakes Feminist Geography Collective, forthcoming, "For slow scholarship: a feminist politics of resistance through collective action in the neoliberal university. ACME: International E-Journal of Critical Geographies

Grundy J and Boudreau J.A, 2008. “ Living with culture: Creative citizenship practices in Toronto" Citizenship Studies 12 347-363

Hanhardt C, 2013, Safe Space: Gay Neighborhood History and the Politics of Violence (Duke University Press, Durham)

Harvie J, 2013, Fair Play: Art, Performance and Neoliberalism (Routledge: London)

hooks b, 1992, Black Looks: Race and Representation (Routledge: New York)

Hubbard P, 2003, "Making space for sex work: female street prostitution and the production of urban space." International Journal of Urban and Regional Research 27 75-89

Hubbard P and Wilkinson E, 2015, "Welcoming the World? Hospitality, Homonationalism, and the London 2012 Olympics" Antipode 47 599-615

Hutcheson M, 2006, "Stories from the badlands" Women and Environments International Magazine 72/73

Kern L and Wekerle G, 2008, "Gendered spaces of redevelopment, gendered politics of city building" in Research in Urban Sociology: Gender in an Urban World Ed. J DeSena (Jai Press/Emerald: Bingley)

Kern L, 2012, "Connecting embodiment, emotion, and gentrification: An exploration through the practice of yoga in Toronto" Emotion, Space, and Society 5 27-35

Kern L, 2015, "From toxic wreck to crunchy chic: environmental gentrification through the body" Environment and Planning D: Society and Space 33 67-83 
Kern L and Mullings B, (2013) "Urban neoliberalism, urban security and urban violence: Exploring the gendered dimensions" in Rethinking Feminist Interventions into the Urban Eds. L Peake and M Reiker (Routledge, London)

Khosla P, 2003, If Low Income Women of Colour Counted in Toronto (Community Social Planning Council Toronto: Toronto)

King M, 2011, "The foster children of Buddies: Queer women at 12 Alexander" Theatre and Performance in Toronto Ed. L. Levin (Playwrights Canada Press, Toronto)

Kipfer S and Petrunia J, 2009, "Colonization and public housing in the competitive city: a Toronto case study" Studies in Political Economy 83 111-39

Klein N, 2014, "How a Cree woman fell to death, and no one saw anything" Globe and Mail, December 19

Kwon M W, 2004, One Place After Another Site-Specific Art and Locational Identity. MIT Press: Cambridge)

Landry C, 2000, The Creative City: A Toolkit for Urban Innovators (Earthscan, London)

Larner W, 2011, "C-Change? Geographies of crisis," Dialogues in Human Geography 1 $319-335$.

Levin L and Solga K, 2009, "Building utopia: Performance and the fantasy of urban renewal in contemporary Toronto" TDR: The Drama Review 53 37-53

Maranda M, 2009, Waging Culture: A Report on the Socio-Economic Status of Canadian Visual Artist (The Art Gallery of York University, Toronto)

McLean H, 2014, "Digging into the creative city: A feminist critique" Antipode 46 669690

McRobbie A, 2011, "Rethinking creative economies as radical social enterprise" Variant $4132-33$

Micallef S (2013) Regent Park: A Story of Collective Impact (The Metcalfe Foundation: Toronto)

Muller Myrdahl T, 2011, "Queerying creative cities," in Queerying Planning: Challenging Heteronormative Assumptions and Reframing Planning Practice Ed. P L Doan (Ashgate: Burlington) 
McKittrick K and Woods C, 2007, Black Geographies and the Politics of Place (South End Press, Cambridge)

Muñoz J, 1999, Disidentifications: Queers of Color and the Performance of Politics (University of Minnesota Press, Minneapolis)

Nagam J, 2009, "Digging up indigenous history in Toronto's cityscape" Canadian Dimension 43 54-55

Nagar R, 2014, Muddying the Waters: Co-Authoring Feminisms Through Scholarship and Activism (University of Illinois Press, Champaign).

Nari, 2015, http://therealnari.tumblr.com/post/66861420394/nari-aka-mc-jazz

Ong, A, 2013, Neoliberalism as Exception: Mutations in Citizenship and Sovereignty (Duke University Press, Durham, NC)

Operation Snatch, 2012, http://operationsnatchblog. wordpress.com/the-artists-and-collaborators/

Oswin N, 2005 "Towards Geographies of Complicit Queer Futures" ACME:

International E-Journal of Critical Geographies 3, 2

Oswin N, 2006 "Decentering queer globalization: Diffusion and the 'global gay'." Environment and Planning D: Society and Space 24 777-790.

Oswin N, 2012, "The queer time of creative urbanism: Family, futurity and global city Singapore" Environment and Planning A 44 1624-1640

Oswin N 2014, "Queer time in global city Singapore: neoliberal futures and the 'freedom to love'." Sexualities 17(4): 412-433.

Parker B, 2008, Beyond the class act: Gender and race in the "creative city" discourse, in Gender in an Urban World: Research in Urban Sociology Ed J DeSena (Jai Press/Emerald:Bingley)

Peck J, 2005, "Struggling with the creative class" International Journal of Urban and Regional Research 29 740-770

Peck J, 2011, Creative moments: Working culture, through municipal socialism and neoliberal urbanism, in Mobile Urbanism. Eds E McCann and K Ward (University of Minneapolis Press, Minneapolis

Peake L and Rieker M, 2013, Rethinking Feminist Interventions into the Urban (Routledge, New York) 
Pratt G and Kirby E, 2003, "Performing nursing: BC nurses' union theatre project" ACME An International E-Journal for Critical Geographies 2 1-19

Rahder B and McLean H, 2013, "Other ways of knowing your place: Immigrant women's experience of public space in Toronto." Canadian Journal of Urban Research 22 145-166

Rankin K and Delaney J, 2011, "Community BIAs as practices of assemblage:

Contingent politics in the neoliberal city." Environment and Planning A 43 1363-1380

Rankin K and Mclean H, 2014, "Governing the Commercial Streets of the City: New Terrains of Disinvestment and Gentrification in Toronto's Inner Suburbs," Antipode 47 216-239

Razack S, 2002, Race, Space and the Law: Unmapping a White Settler Society (Between the Lines, Toronto)

Rogoff I, 2006, "Smuggling - An Embodies Criticality"

http://curatorial.net/resources/Rogoff_Smuggling.pdf

Ross B, 2009, Burlesque West: Showgirls, Sex and Sin in Postwar Vancouver (University of Toronto Press: Toronto)

Robertson C, 2006, Policy Matters: Administrations of Art and Culture (YYZ Books, Toronto)

Schulman S, 2012, The Gentrification of the Mind (University of California Press, Berkeley, CA)

Sharp J, 2008, Geographies of Postcolonialism (Sage Publications, London)

Tigchelaar A (forthcoming) "The creative ass class" Adaptive Actions (Heteropolis. Montreal: Adaptive Actions)

Taylor D, 2003, The Archive and the Repertoire: Performing Cultural Memory in the Americas (Duke University Press: Durham)

Tuhiwai Smith L, 1999, Decolonizing Methodologies: Research and Indigenous Peoples (Zed Books, London) 
Walcott R (2001) "Blue print for resistance: Art, nation, and citizenship," in Money, Value, Art: State Funding, Free Markets, Big Pictures Eds. In S McKay and A J Patterson (YYZ Books: Toronto)

Ward K, 2011, "Policies in motion and in place: The case of the Business Improvement Districts," in Mobile Urbanism, ed. E McCann and K Ward (Minnesota University Press, Minneapolis)

Zukin S, 1982, Loft Living Culture and Capital in Urban Change (John Hopkins University Press, Baltimore MD) 